\title{
Influence of cigarette smoke combined with different toothpastes on enamel erosion
}

\author{
Laura Nobre FERRAZ(a) \\ Núbia Inocêncya Pavesi PINI(b) iD \\ Gláucia Maria Bovi \\ AMBROSANO(c) \\ Flávio Henrique Baggio \\ AGUIAR(a) $^{(a)}$ \\ Débora Alves Nunes Leite \\ LIMA $^{(a)}$ \\ (a) Universidade Estadual de Campinas \\ - Unicamp, Piracicaba Dental School, \\ Department of Restorative Dentistry, \\ Piracicaba, SP, Brazil. \\ (b)Ingá University Center - Uningá, Maringá, \\ PR, Brazil. \\ (c) Universidade Estadual de Campinas \\ - Unicamp, Piracicaba Dental School, \\ Department of Social Dentistry, Piracicaba, \\ SP, Brazil.
}

Declaration of Interests: The authors certify that they have no commercial or associative interest that represents a conflict of interest in connection with the manuscript.

\section{Corresponding Author:}

Laura Nobre Ferraz

nobreferraz@hotmail.com

https://doi.org/10.1590/1807-3107bor- 2019.vol33.0114

Submitted: July 20, 2018

Accepted for publication: May 14, 2019

Last revision: November 4, 2019

\begin{abstract}
This in vitro study aimed to evaluate the effect of different toothpastes on dental enamel subjected to an erosive cycle with and without exposure to cigarette smoke. Bovine enamel specimens were randomly allocated into 12 groups $(n=12)$. For the in vitro simulation of smoking, half the groups underwent an exposure cycle of 20 cigarettes per day for 5 days. Subsequently, all groups were subjected to a 5-day erosion cycle intercalating demineralization ( $1 \mathrm{~min}$; $1 \%$ citric acid; $\mathrm{pH}=3.5)$ and treatment with toothpaste slurries (2 min) of $\mathrm{NaF}, \mathrm{SnF}_{2}$, $\mathrm{F} / \mathrm{Sn} / \mathrm{Chitosan}, \mathrm{F} / \mathrm{CaSiO}_{3} / \mathrm{Na}_{3} \mathrm{PO}_{4}$, and $\mathrm{F} /$ bioactive glass. The control group was immersed in distilled water. Surface microhardness (SMH) was measured initially, after exposure to smoke, and after the erosive cycle, and \%SMH was calculated. At the end of the experimental cycle, surface roughness, profilometry, and atomic force microscopy (AFM) were performed. SMH increased after exposure to cigarette smoke $(p<0.05)$. After the erosive cycle, there were no differences between the presence and absence of cigarette smoke exposure in $\mathrm{SMH}$ and roughness $(\mathrm{p}>0.05)$. Besides increasing enamel $\mathrm{SMH}$, cigarette smoke did not prevent enamel loss after the erosion cycle $(p<0.05)$. In profilometry, roughness and surface loss had the lowest values in the groups treated with $\mathrm{SnF}_{2}$ and $\mathrm{F} / \mathrm{Sn} /$ Chitosan $(\mathrm{p}<0.05)$. AFM showed lower mineral loss with $\mathrm{F} / \mathrm{CaSiO} / \mathrm{Na}_{3} \mathrm{PO}_{4}$ and $\mathrm{F} / \mathrm{Sn} / \mathrm{Chitosan}$. For all groups, except $\mathrm{F} / \mathrm{CaSiO} / \mathrm{Na}_{3} \mathrm{PO}_{4}$, cigarette smoke resulted in higher enamel wear. $\mathrm{F} / \mathrm{Sn} / \mathrm{Chitosan}$ showed the best results against erosion.
\end{abstract}

Keywords: Tooth Erosion; Toothpastes; Dental Enamel; Smoking.

\section{Introduction}

Dental erosion is a condition in which non-bacterial acids cause demineralization of dental hard tissues. ${ }^{1}$ Although acid contact is the main cause of erosion, its development involves a complex interaction among biological, chemical, and behavioral factors in each patient. ${ }^{1}$ A common behavioral factor is smoking. The smoking by itself does not cause dental erosion, often associated with consumption of acidic beverages ${ }^{1,2}$ that influences the development of dental erosion. ${ }^{1}$

Smoking cigarettes is often accompanied with prolonged consumption of acidic drinks, such as alcoholic beverages ${ }^{2}$. Excessive alcohol intake is associated with a high prevalence of erosion because of the direct effect 
of alcohol and its association with regular vomiting or alcohol-induced gastroesophageal reflux. ${ }^{3}$ Tobacco is commonly consumed by adolescents with eating disorders, ${ }^{3}$ and it inhibits appetite in people with anorexia nervosa. ${ }^{3}$ As smoking is frequently associated with episodes of low $\mathrm{pH}$, studies evaluating this association are necessary to determine the effect of smoking on the severity of dental erosion.

During smoking, teeth are exposed to hot smoke from tobacco combustion. The temperature of tobacco pyrolysis and cigarette combustion is $300^{\circ} \mathrm{C}-1,000^{\circ} \mathrm{C}{ }^{4}$ This hot smoke can heat the dental enamel, at high temperatures causing changes in the arrangement and morphology of the hydroxyapatite crystals. ${ }^{5}$ In addition, the components of cigarette smoke result in accumulation of contaminants on the calcified tissues and restorative materials. ${ }^{6}$ Although the effects of cigarette smoke on enamel are known, no studies have assessed the impact of these changes on the susceptibility to dental erosion.

As a therapeutic measure for eroding dental surfaces, their resistance to erosion can be increased, either by modifying the crystalline structure, making them less soluble, or by providing protective organic layers on dental tissues. ${ }^{7}$ Toothpastes are the ideal therapy for eroded dental tissues. ${ }^{8}$ The action of toothpastes is mainly associated with fluoride, which precipitates a $\mathrm{CaF}_{2}$ layer on demineralized dental tissues. Although partially, this can reduce enamel susceptibility to demineralization. ${ }^{9} \mathrm{CaF}_{2}$ precipitates may act as a barrier on dental structures, preventing their direct contact with acids. ${ }^{10}$ However, under conditions promoting erosion, such as low $\mathrm{pH}$, this barrier is not stable against erosive wear. ${ }^{7}$ Due to the limited efficacy of fluoride in such cases, the treatment and prevention of dental erosion should combine it with other active agents. ${ }^{7}$ The compounds of fluoride with metal cations, such as $\mathrm{SnF}_{2}$, prevent or decrease tissue loss during acidic events. ${ }^{11}$ Alternatively, biopolymers, such as chitosan, ${ }^{12}$ combined with $\mathrm{SnF}_{2}$ can be used. Recently, commercially available bioactive glass (e.g. $\mathrm{CaNaO}_{6} \mathrm{PSi}$ ) and the addition of calcium minerals (e.g. $\mathrm{CaSiO}_{3}$ ) to fluoride-containing toothpastes have prevented and treated dental erosion. ${ }^{7}$

There is no evidence that the effects of cigarette smoking on enamel may influence erosion and may be treated with toothpastes. Therefore, this in vitro study aimed to evaluate the effect of different active compounds associated with fluoride on dental enamel with or without cigarette smoke, and submitted to cyclic episodes of enamel erosion.

\section{Methodology}

\section{Experimental design}

This in vitro study tested the factors cigarette smoke (2 levels: with or without cigarette smoke) and toothpastes (6 levels: Distilled Water, $\mathrm{NaF}, \mathrm{SnF}_{2}$, $\mathrm{F} / \mathrm{Sn} /$ chitosan, $\mathrm{F} / \mathrm{CaSiO}{ }_{3} / \mathrm{Na}_{3} \mathrm{PO}_{4}$ and $\mathrm{F} /$ bioactive glass). Figure 1 shows the study design including experimental processes. Bovine enamel specimens were used and randomly allocated into 12 groups ( $\mathrm{n}=12$ ): distilled water, $\mathrm{NaF}, \mathrm{SnF}_{2}, \mathrm{~F} / \mathrm{Sn} /$ Chitosan, $\mathrm{F} / \mathrm{CaSiO}_{3} / \mathrm{Na}_{3} \mathrm{PO}$, and $\mathrm{F} /$ bioactive glass groups, each with and without cigarette smoke. The sample size was based on literature. ${ }^{13}$ Human saliva was used for pellicle formation. The analyses were of surface microhardness $(\mathrm{SMH})$, tested thrice (SMH1, baseline; $\mathrm{SMH} 2$, after exposure to cigarette smoke or not; $\mathrm{SMH}$, after erosive treatment), surface roughness ( $\mathrm{Ra})$, surface profilometry, and atomic force microscopy (AFM). Table 1 shows toothpaste information.

\section{Volunteers and ethical aspects}

This study was conducted according to the Declaration of Helsinki and approved by the local ethics committee in research (process $\mathrm{N}^{\mathrm{o}}$ : 55288216.5). The participants were 12 volunteers (6 men and 6 women), 23-35 years old, who signed a consent form. The volunteers fulfilled the inclusion criteria (normal salivary flow, absence of caries and periodontal disease, healthy or sufficiently restored dentition, and adequate oral hygiene) without violating the exclusion criteria (use of orthodontic devices or prostheses and drugs interfering with salivary flow, smoking, pregnancy or lactation, allergy to oral hygiene products, dental materials, or therapeutic agents used in the study).

\section{Saliva collection}

All the natural saliva was collected from the volunteers before the experiment. Oral hygiene 


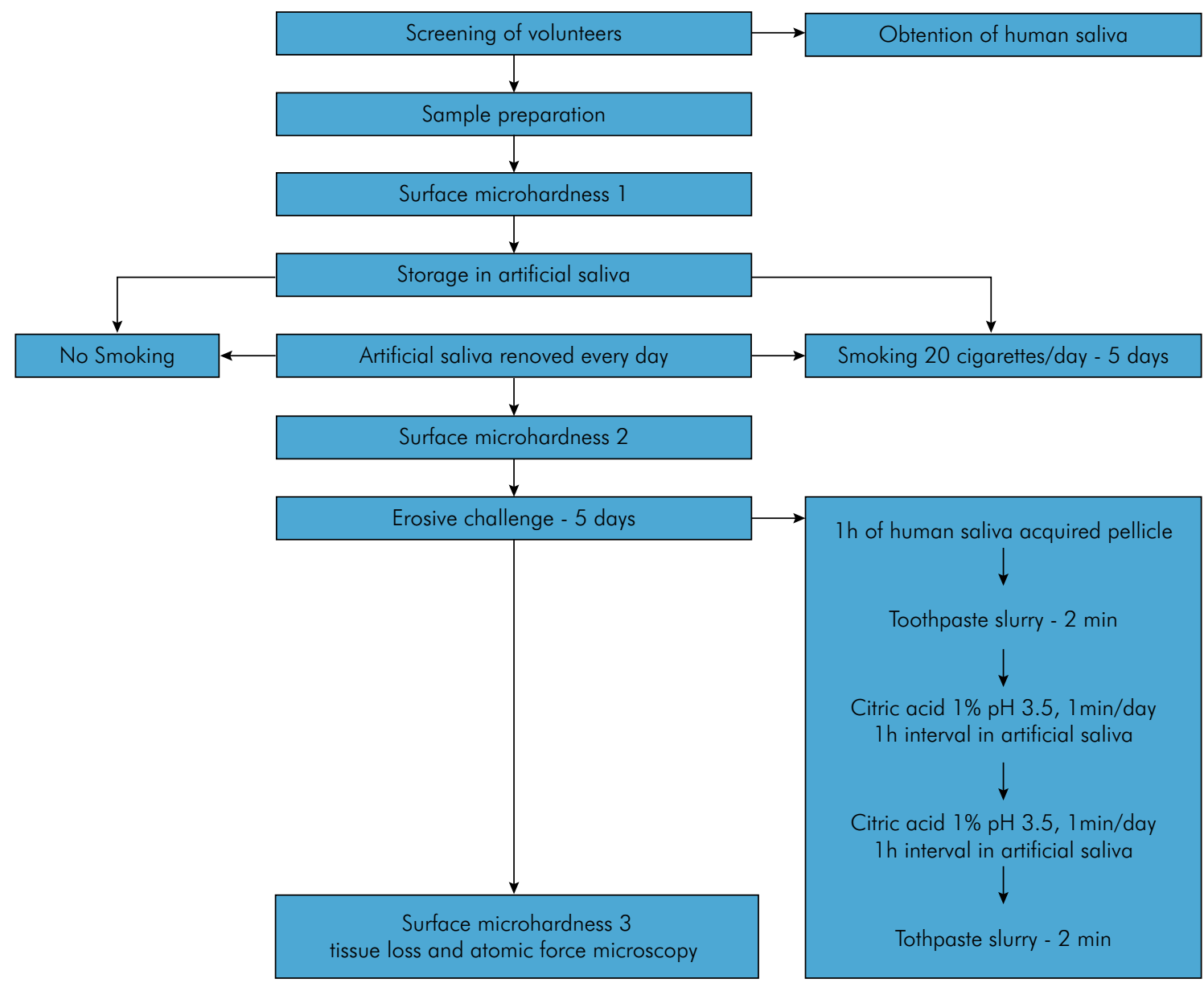

Figure 1. Flow diagram of the experimental process.

measures and breakfast were prohibited. Salivary flow was stimulated by chewing paraffin wax (Parafilm M, American National Can, Chicago, USA), and saliva was collected in falcon tubes inside a beaker filled with ice blocks. Subsequently, a salivary pool was made from the volunteers, which was clarified by centrifugation (JOUAN MR23i Benchtop High Speed Centrifuge Thermo Scientific MR23i, Waltham, USA) at $3.800 \mathrm{~g}$ for $10 \mathrm{~min}$ at $4^{\circ} \mathrm{C}$. The precipitate was discarded, and the supernatant was stored in a freezer at $-80^{\circ} \mathrm{C}$. This was performed for 3 days to obtain $800 \mathrm{~mL}$ of saliva. For pellicle formation, aliquots of saliva were daily thawed at room temperature and mixed before use.

\section{Specimen preparation}

A total of 144 enamel/dentin specimens $(4 \times 4 \mathrm{~mm})$ were obtained from bovine incisors stored in $0.1 \%$ thymol solution, using a precision saw (Isomet 1000; Buehler, IL, USA) and diamond disc (Buehler, USA). The enamel surface was planned and flattened using silicon carbide papers (500-, 1000-, and 2000-SiC; Buehler, USA) and felts (TCT, TWI, and FVC; Arotec, Cotia, Brazil) coupled with a diamond paste $(6,3$, and $0.75 \mu \mathrm{m}$, Buehler, USA) in a polishing machine, under water cooling (Arotec, São Paulo, SP, Brazil). Subsequently, the specimens were placed in an ultrasonic machine for $10 \mathrm{~min}$ (Marconi, Piracicaba, Brazil) to remove residual particles and smear layers and obtain a standardized enamel surface. Finally, the specimens contained enamel and dentin, each $1 \mathrm{~mm}$ thick. The specimen surfaces, except the enamel surface, were protected with acid-resistant varnish (Risqué Colorless, Taboão da Serra, Brazil). Prior to (24 h) and during the experiment, the prepared specimens 
Table 1. Products, manufacturers, and components of toothpaste.

\begin{tabular}{|c|c|c|c|c|}
\hline Toothpaste & Manufacturer & Active agent & Fluoride agent & Other components \\
\hline $\begin{array}{l}\text { Colgate Total } 12^{\mathrm{TM}} \\
(\mathrm{NaF})\end{array}$ & $\begin{array}{l}\text { Colgate-Palmolive, } \\
\text { São Bernardo do } \\
\text { Campo, Brazil }\end{array}$ & - & $\begin{array}{l}\text { Sodium fluoride (NaF) } \\
1450 \mathrm{ppm}\end{array}$ & $\begin{array}{l}\text { Water, Triclosan, Sorbitol, Hydrated Silica, } \\
\text { Sodium Lauryl Sulfate, PVM/MA Copolymer, } \\
\text { Flavor Carrageenan, Sodium Hydroxide, Sodium } \\
\text { Saccharin, Titanium dioxide, and Dipentene. }\end{array}$ \\
\hline \multirow{5}{*}{$\begin{array}{l}\text { Crest }^{\mathrm{TM}} \text { Pro Health } \\
\text { Advanced }\left(\mathrm{SnF}_{2}\right)\end{array}$} & \multirow{5}{*}{$\begin{array}{l}\text { Procter \& Gamble, } \\
\text { Cincinnati, Ohio, } \\
\text { United States }\end{array}$} & & \multirow{5}{*}{$\begin{array}{l}\text { Stannous fluoride }\left(\mathrm{SnF}_{2}\right) \\
0,454 \%\end{array}$} & Glycerin, Hydrated Silica, Sodium \\
\hline & & & & $\begin{array}{c}\text { Hexametaphosphate, Propylene Glycol, PEG } \\
\text { 6, Water, Zinc Lactate, }\end{array}$ \\
\hline & & & & $\begin{array}{c}\text { Trisodium Phosphate, Flavor, Sodium Lauryl } \\
\text { Sulfate, Sodium }\end{array}$ \\
\hline & & & & $\begin{array}{l}\text { Gluconate, Carrageenan, Sodium Saccharin, } \\
\text { Polyethylene, Xanthan }\end{array}$ \\
\hline & & & & Gum, Mica, Titanium Dioxide, Blue 1 \\
\hline $\begin{array}{l}\text { Elmex }{ }^{T M} \text { Erosion } \\
\text { Protection }^{T M} \\
\text { (F/Sn/chitosan) }\end{array}$ & $\begin{array}{l}\text { GABA } \\
\text { International AG, } \\
\text { Grabetsmattweg, } \\
\text { Switzerland }\end{array}$ & $\begin{array}{l}\text { Chitosan (0.5\%), } \\
\text { Stannous Chloride }\end{array}$ & $\begin{array}{l}\text { Amine Fluoride (AmF) } \\
700 \text { ppm, Sodium } \\
\text { Fluoride (NaF) } 700 \text { ppm }\end{array}$ & $\begin{array}{c}\text { Glycerin Hydrated, Silica, Sodium } \\
\text { hexametaphosphate, Propylene glycol, PEG-6, } \\
\text { Eau, Zinc lactate, trisodium phosphate, flavor, } \\
\text { Sodium lauryl sulfate, Polyethylene, Sodium, } \\
\text { Gluconate, Carrageenan, Sodium saccharin, } \\
\text { Xanthan gum, Titanium dioxide, red } 40 \\
\text { aluminium lake }\end{array}$ \\
\hline $\begin{array}{l}\text { Regenerate }^{\mathrm{TM}} \\
\text { Enamel Science } \\
\text { (F/CaSiO3/Na3PO4) }\end{array}$ & $\begin{array}{l}\text { Unilever France } \\
\mathrm{HCl} \text {, Le Meux, } \\
\text { France }\end{array}$ & $\begin{array}{l}\text { Calcium Silicate, } \\
\text { Sodium Phosphate }\end{array}$ & $\begin{array}{l}\text { Sodium } \\
\text { Monofluorophosphate } \\
\text { (MFP) } 1450 \text { ppm }\end{array}$ & $\begin{array}{l}\text { Glycerin, PEG-8, Hydrate Silica, Trisodium } \\
\text { Phosphate, Water, PEG-60, Sodium Lauryl } \\
\text { Sulfate, Aroma, Synthetic Fluorphlogopite, Sodium } \\
\text { Saccharin, Polyacrylic Acid, Limonene, Tin Oxide }\end{array}$ \\
\hline $\begin{array}{l}\text { Sensodyne }{ }^{T M} \text { Repair } \\
\text { \& Protect } \\
\text { Novamin }^{\text {TM }} \\
\text { Technology } \\
\text { (F/bioactive glass) }\end{array}$ & $\begin{array}{c}\text { SmithKline } \\
\text { Beecham Consumer } \\
\text { Healthcare, } \\
\text { Berkshire, United } \\
\text { Kingdom }\end{array}$ & $\begin{array}{l}\text { Calcium Sodium } \\
\text { Phosphosilicate }\end{array}$ & $\begin{array}{l}\text { Sodium } \\
\text { Monofluorophosphate } \\
\text { (MFP) } 1426 \text { ppm }\end{array}$ & $\begin{array}{c}\text { Glycerin, silica, PEG-8, Titanium Dioxide, } \\
\text { Carbomer, Cocamidopropyl Betaine, Sodium } \\
\text { Methyl Cocoyl Taurate, Sodium Saccharin, } \\
\text { d-limonene }\end{array}$ \\
\hline
\end{tabular}

were stored in a $37^{\circ} \mathrm{C}$ incubator and artificial saliva, which was renewed every day. The artificial saliva contained $1.5 \mathrm{mM}$ of $\mathrm{Ca}, 0.9 \mathrm{mM}$ of $\mathrm{PO}_{4}$, and $150 \mathrm{mM}$ of $\mathrm{KCl}$, in $20 \mathrm{mM}$ of Tris $\mathrm{pH} 7.0^{14}$.

\section{Exposure to cigarette smoke}

The specimens from 6 groups were exposed to cigarette smoke, while the others were stored in artificial saliva. The in vitro simulation of smoking was performed in a smoke machine (registration no. 01810012043 INPI; National Institute of Industrial Property). Each specimen was exposed to 20 cigarettes (Marlboro, Philip Morris Brazil Ind and Com, RS, Brazil) per day for 5 days. ${ }^{15}$. The cycle was performed with intervals of $3 \mathrm{~s}$, which simulates the aspiration usually performed by a smoker. A temporizer allowed ambient air to be inhaled every $10 \mathrm{~s}$, simulating smoke exhaustion and subsequent disposal. In the interval between 2 simulations, the specimens were stored in artificial saliva at $37^{\circ} \mathrm{C}$.

\section{Erosive challenge}

This erosive cycle simulated the erosion process in the oral cavity, intercalating citric acid demineralization ( $1 \%$ citric acid; $3.5 \mathrm{pH})^{16}$ and treatment with toothpaste slurry. ${ }^{17}$ Half the surface area of the specimens were protected with a layer of acid-resistant varnish (Risqué Colorless) for reference to allow the analysis of surface profilometry after the erosive cycle.

The erosion cycling model was of 5 days. ${ }^{17}$ Before the $1^{\text {st }}$ erosive challenge of each day, the specimens were immersed individually for $1 \mathrm{~h}$ in human saliva at $37^{\circ} \mathrm{C}$ under agitation (100 rpm) and subsequently in the respective erosive solutions for $1 \mathrm{~min}, 4$ times daily, ${ }^{17}$ with $1 \mathrm{~h}$ of interval. Citric acid was handled daily and renewed at each erosion episode. Before the $1^{\text {st }}$ and after the last erosive challenge of each day, the specimens were immersed in the respective treatment slurries (1:3 ratio of toothpaste to distilled water) for $2 \mathrm{~min}$. The treatments were performed 
under agitation (100 rpm) at room temperature. The slurries were handled immediately before use. Between the erosive challenges $(1 \mathrm{~h})$ and after the daily cycle, the specimens were stored in artificial saliva at $37^{\circ} \mathrm{C}$ overnight $(20 \mathrm{~h})$. Before and after immersing the specimens in the erosive solution, slurries, and artificial saliva, they were washed with purified water for $30 \mathrm{~s}$ and dried. The amount of each solution (erosive, toothpaste slurry, and saliva) was the same per specimen $\left(2.5 \mathrm{~mL} / \mathrm{mm}^{2}\right.$ of exposed enamel). Artificial saliva was changed daily.

\section{Microhardness analysis}

SMH was measured to assess the enamel characteristics after the challenges (smoking and erosion/treatment). It was analyzed at three times: baseline (SMH1), after exposure to cigarette smoke (SMH2) and after the end of the erosion cycle (SMH3). A Knoop indenter, loaded with 50 g, with indentation time of $5 \mathrm{~s}$, was used in a microhardness tester (HMV-2000 Shimadzu, Tokyo, Japan). Three indentations, $100 \mu \mathrm{m}$ apart, were made at the center of the enamel surface at different reading times. The mean values of the measuring points were determined $(\mu \mathrm{m})$, and the SMH loss (\%SMH) was calculated using the following formula: $\% \mathrm{SMH}=100$ [(SMHt-SMH1)/SMH1], where " $\mathrm{t}$ " is the time taken to calculate \%SMH. SMH2 was substituted for \%SMH1 (loss after cigarette smoke) and SMH3 for \%SMH2 (loss after the erosive cycle). Higher values of \%SMH indicated higher enamel surface loss.

\section{Tissue loss measurement}

After the last experimental day, the tissue loss was analyzed by surface profilometry (Veeco DEKTAK 150, Veeco, NY, USA). The roughness was measured in the area subjected to erosion and reference area, for which the protective coating was removed. At the center of each specimen, 3 traces were made at intervals of $0.2 \mathrm{~mm}$, each $2 \mathrm{~mm}$ long ( $1 \mathrm{~mm}$ each in the reference and experimental areas). The minimum level detectable by the equipment is $4 \AA$. Two regression lines were constructed for each trait, 1 each in the reference and experimental areas. The vertical distance between the regression lines was defined as tissue loss $(\mu \mathrm{m})$. The value per specimen was the mean of the 3 measurements.

\section{Surface roughness (Ra) and Atomic Force Microscopy}

Ra was evaluated using a rugosimeter (SV-3100S4 - Mitutoyo, Tokyo, Japan) coupled with an atomic force microscope (Easy Scan 2, Nano surf, Boston, USA). The precision was $0.01 \mu \mathrm{m}$, with a cut-off value of $0.25 \mathrm{~mm}$, reading length of 5 times the cut-off value $(1.25 \mathrm{~mm})$, and mean velocity of $0.1 \mathrm{~mm} / \mathrm{s}$. The specimens were placed parallel to the equipment surface and marked with 3 equidistant points at the center to guide the reading. The readings were performed at $180^{\circ}, 135^{\circ}$, and $90^{\circ}$. The atomic force microscope (Easy Scan 2, Nano surf, Boston, USA) was operated in the tapping mode, with a constant of $31-71 \mathrm{~N} / \mathrm{m}$, wavelength of $225 \mu \mathrm{m}$, and resonance frequency of 160-210 KHz. 3D topographic and lock-in phase images $(15 \times 15 \mu \mathrm{m})$ were obtained using a profilometer mounted on the microscope. Specimens from all groups were analyzed. For quantitative analysis of the surface, the mean of the 3 readings was the final Ra. For the qualitative analysis, 1 topographic image and representative lock-in phase images were randomly chosen for samples of each group. The images were processed using the Gwyddion software (Gwyddion 2.29, GNU General Public License).

\section{Statistical analysis}

$\mathrm{SMH}$ and Ra data were analyzed using mixed models for repeated measures analysis of variance (ANOVA) and the Tukey-Kramer test by the PROC MIXED procedure of the SAS program. \%SMH1 data did not meet the ANOVA assumptions and were analyzed using generalized linear models. Contrarily, $\mathrm{SMH} 2 \%$ data met the assumptions and were analyzed by two-way ANOVA and the Tukey's test. \%SMH data were compared to Tukey's. Surface profilometry data indicated a logarithmic transformation to meet the assumptions of a parametric analysis. After the transformation, for these and Ra data were also submitted to ANOVA in $2 \times 6$ (smoke X treatment with toothpastes) factorial scheme and Tukey's test. The analyses had a significance level of $5 \%$. 


\section{Results}

Regarding SMH (Table 2), triple interaction among the factors (treatment, smoke, and time) was significant ( $p=0.0429)$ and therefore deployed to compare the levels of the 3 factors. In SMH2, groups exposed to cigarette smoke were significantly different from those that were not $(p<0.05)$. In the smoking groups, $\mathrm{SMH} 2$ was significantly higher than SMH1 ( $p<0.05)$. Irrespective of the treatment, all groups showed significant reduction from $\mathrm{SMH} 1$ and SMH2 to SMH3 ( $p$ < 0.05). All toothpastes showed significant differences compared to distilled water $(\mathrm{p}<0.05)$. Among the toothpastes, $\mathrm{NaF}$ showed the lowest $\mathrm{SMH}$ values $(\mathrm{p}<0.05)$. No difference was found between $\mathrm{SnF}_{2}$ and $\mathrm{F}$ /bioactive glass ( $\mathrm{p}>0.05$ ). F/Sn/chitosan and $\mathrm{F} / \mathrm{CaSiO}{ }_{3} / \mathrm{Na}_{3} \mathrm{PO}_{4}$ showed the highest $\mathrm{SMH}$, without significant differences between them ( $p>0.05)$. \%SMH2 was statistically different from \%SMH1, after higher enamel loss was found from erosive challenge $(\mathrm{p}<0.05) . \%$ SMH1 did not significantly differ among treatments $(p>0.05)$ but did between presence and absence of cigarette smoke exposure $(\mathrm{p}<0.05)$. $\% \mathrm{SMH} 2$ was the same as \%SMH3 in toothpaste effectiveness and significantly differed between presence and absence of cigarette smoke exposure for Sn-based toothpastes ( $\mathrm{p}<0.05)$. When exposed to cigarette smoke, $\mathrm{SnF}_{2}$ showed lower \%SMH and $\mathrm{F} / \mathrm{Sn} /$ chitosan showed higher \%SMH.

In profilometry (Table 3), interaction between the factors (treatment and smoke) was not significant $(p=0.1035)$. Exposure to cigarette smoke resulted in higher tissue loss ( 10\%) irrespective of the toothpaste slurry ( $\mathrm{p}<0.05)$, except for $\mathrm{F} / \mathrm{CaCO} \mathrm{Ca}_{3} / \mathrm{Na}_{3} \mathrm{PO}_{4}$, in which cigarette smoke resulted in less tissue loss. All treatment groups significantly differed from the distilled water group $(\mathrm{p}<0.05)$. $\mathrm{NaF}, \mathrm{F} / \mathrm{CaSiO} \mathrm{O}_{3} / \mathrm{Na}_{3} \mathrm{PO}_{4 \prime}$ and $\mathrm{F} /$ bioactive glass had no differences ( $p>0.05)$, with $20-30 \%$ of tissue loss reduction, compared to distilled water. $\mathrm{SnF}_{2}$ and $\mathrm{F} / \mathrm{Sn} /$ chitosan showed the lowest values of tissue loss, with a tissue loss reduction of $78 \%(\mathrm{p}<0.05)$.

Regarding surface roughness interaction between the factors (treatment and smoke) was not significant $(p=0.3244)$. The exposure to smoking did not affect the Ra values ( $p>0.05$ ) (Table 3). All treatment groups were statistically different from the distilled water group ( $\mathrm{p}<0.05$ ). $\mathrm{NaF}$ and $\mathrm{F} /$ bioactive glass showed the lowest values $(\mathrm{p}<0.05)$. $\mathrm{F} / \mathrm{CaSiO} \mathrm{O}_{3} / \mathrm{Na}_{3} \mathrm{PO}_{4}$ showed intermediate values, while SnF2 and F/Sn/chitosan showed the lowest mean $\operatorname{Ra}(\mathrm{p}<0.05)$.

Table 2. Results (mean \pm standard deviation) of surface microhardness (SMH) and \%SMH based on treatment and time.

\begin{tabular}{|c|c|c|c|c|c|c|}
\hline \multirow{2}{*}{$\begin{array}{l}\text { Cigarette } \\
\text { smoke }\end{array}$} & \multirow{2}{*}{ Treatment } & \multicolumn{3}{|c|}{ Time } & \multirow{2}{*}{$\%$ SMHI } & \multirow{2}{*}{$\% \mathrm{SMH} 2$} \\
\hline & & $\mathrm{SMHI}$ & $\mathrm{SMH} 2$ & SMH3 & & \\
\hline \multirow{6}{*}{ Without } & Distilled Water & $316.07 \pm 10.0 \mathrm{Aa}$ & $* 320.55 \pm 9.7 \mathrm{Aa}$ & $79.41 \pm 3.9 \mathrm{Bd}$ & $* 1.42(0.46) \mathrm{Ba}$ & $-74.87(1.18) \mathrm{Ad}$ \\
\hline & $\mathrm{NaF}$ & $316.19 \pm 10.5 \mathrm{Aa}$ & $* 318.98 \pm 10.8 \mathrm{Aa}$ & $103.21 \pm 4.4 \mathrm{Bc}$ & *0.88 (0.78) Ba & $-67.36(0.81) A c$ \\
\hline & $\mathrm{SnF}_{2}$ & $316.45 \pm 10.5 \mathrm{Aa}$ & ${ }^{*} 319.97 \pm 10.4 \mathrm{Aa}$ & $119.674 .7 \mathrm{Bb}$ & ${ }^{*} 1.12(0.40) \mathrm{Ba}$ & ${ }^{*}-62.17(1.46) \mathrm{Ab}$ \\
\hline & $\mathrm{F} / \mathrm{Sn} /$ chitosan & $316.07 \pm 9.3 \mathrm{Aa}$ & ${ }^{*} 319.86 \pm 8.8 \mathrm{Aa}$ & $152.71 \pm 8.7 \mathrm{Ba}$ & ${ }^{*} 1.21(0.56) \mathrm{Ba}$ & *-51.68 (2.60) Aa \\
\hline & $\mathrm{F} / \mathrm{CaSiO} / 3 / \mathrm{Na}_{3} \mathrm{PO}_{4}$ & $316.01 \pm 10.5 \mathrm{Aa}$ & $* 319.10 \pm 9.8 \mathrm{Aa}$ & $156.14 \pm 8.7 \mathrm{Ba}$ & ${ }^{*} 0.99(0.63) \mathrm{Ba}$ & $-50.60(2.08) \mathrm{Aa}$ \\
\hline & F/bioactive glass & $316.28 \pm 10.3 \mathrm{Aa}$ & $* 318.95 \pm 9.6 \mathrm{Aa}$ & $122.26 \pm 9.3 \mathrm{Bb}$ & *0.85 (0.43) Ba & $-61.37(2.17) \mathrm{Ab}$ \\
\hline \multirow{6}{*}{ With } & Distilled Water & $316.00 \pm 10.3 \mathrm{Ba}$ & $347.32 \pm 11.2 \mathrm{Aa}$ & $84.04 \pm 4.0 \mathrm{Cd}$ & $9.92(1.64) \mathrm{Ba}$ & $-73.38(1.48) \mathrm{Ad}$ \\
\hline & $\mathrm{NaF}$ & $316.31 \pm 9.7 \mathrm{Ba}$ & $345.41 \pm 9.0 \mathrm{Aa}$ & $107.16 \pm 3.6 \mathrm{Cc}$ & $9.24(2.44) \mathrm{Ba}$ & $-66.10(1.30) A c$ \\
\hline & $\mathrm{SnF}_{2}$ & $316.27 \pm 12.4 \mathrm{Ba}$ & $343.55 \pm 9.4 \mathrm{Aa}$ & $127.54 \pm 5.3 \mathrm{Cb}$ & $8.69(2.44) \mathrm{Ba}$ & $-59.64(1.73) A b$ \\
\hline & $\mathrm{F} / \mathrm{Sn} /$ chitosan & $316.26 \pm 12.2 \mathrm{Ba}$ & $346.27 \pm 8.5 \mathrm{Aa}$ & $145.02 \pm 3.4 \mathrm{Ca}$ & $9.58(3.31) \mathrm{Ba}$ & $-54.10(1.70) \mathrm{Aa}$ \\
\hline & $\mathrm{F} / \mathrm{CaSiO}{ }_{3} / \mathrm{Na}_{3} \mathrm{PO}_{4}$ & $316.13 \pm 12.3 \mathrm{Ba}$ & $345.61 \pm 8.8 \mathrm{Aa}$ & $151.26 \pm 3.9 \mathrm{Ca}$ & $9.42(3.53) \mathrm{Ba}$ & $-52.07(2.50) \mathrm{Aa}$ \\
\hline & F/bioactive glass & $316.13 \pm 9.5 \mathrm{Ba}$ & $344.22 \pm 7.6 \mathrm{Aa}$ & $124.81 \pm 4.6 \mathrm{Cb}$ & $8.92(1.65) \mathrm{Ba}$ & $-60.50(1.60) \mathrm{Ab}$ \\
\hline
\end{tabular}

p-values: treatment, $<0.0001$; smoke, $<0.0001$; time, $<0.0001$; treatment and smoke, $=0.8931$; treatment and time, $<0.0001 ;$ smoke and time, $<0.0001$; treatment, smoke, and time, $=0.0429 .{ }^{*}$ differs from the group with cigarette smoke exposure at the same treatment conditions and time $(p \leq 0.05)$. Means followed by distinct letters (horizontal uppercase and vertical lower case comparing treatment within each smoking level) indicate statistically significant differences ( $p \leq 0.05)$. SMH1, baseline; SMH2, after exposure to cigarette smoke; SMH3, after the end of the erosion cycle; \%SMH1, percentage of surface hardness loss after exposure to cigarette smoke; \%SMH2, percentage of surface hardness loss after erosion cycle. 
Table 3. Results (mean \pm standard deviation) of tissue loss $(\mu \mathrm{m})$ and surface roughness $(\mathrm{nm})$ based on treatment with toothpastes and exposure to cigarette smoke.

\begin{tabular}{lcccc}
\hline \multirow{2}{*}{ Treatment } & \multicolumn{2}{c}{ Surface profilometry } & \multicolumn{2}{c}{ Surface roughness } \\
\cline { 2 - 5 } & \multicolumn{2}{c}{ Cigarette smoke } & With & Cigarette smoke \\
\cline { 2 - 5 } Distilled water & $2.92 \pm 0.8 \mathrm{Ba}$ & $3.6 \pm 0.7 \mathrm{Aa}$ & $177.75 \pm 19.2 \mathrm{Aa}$ & $175.33 \pm 26.5 \mathrm{Aa}$ \\
$\mathrm{NaF}$ & $2.54 \pm 0.2 \mathrm{Bb}$ & $2.8 \pm 0.4 \mathrm{Ab}$ & $141.58 \pm 20.1 \mathrm{Ab}$ & $156.08 \pm 17.5 \mathrm{Ab}$ \\
$\mathrm{SnF}_{2}$ & $0.7 \pm 0.1 \mathrm{Bc}$ & $0.79 \pm 0.1 \mathrm{Ac}$ & $58.42 \pm 15.6 \mathrm{Ad}$ & $58.25 \pm 15.5 \mathrm{Ad}$ \\
$\mathrm{F} / \mathrm{Sn} /$ chitosan & $0.66 \pm 0.1 \mathrm{Bc}$ & $0.73 \pm 0.1 \mathrm{Ac}$ & $49.42 \pm 11.8 \mathrm{Ad}$ & $57.75 \pm 16.5 \mathrm{Ad}$ \\
$\mathrm{F} / \mathrm{CaSiO}_{3} / \mathrm{Na}_{3} \mathrm{PO}_{4}$ & $2.79 \pm 0.5 \mathrm{Bb}$ & $2.48 \pm 0.5 \mathrm{Ab}$ & $100.50 \pm 16.9 \mathrm{Ac}$ & $109.33 \pm 18.7 \mathrm{Ac}$ \\
$\mathrm{F} /$ bioactive glass & $2.51 \pm 0.5 \mathrm{Bb}$ & $2.85 \pm 0.5 \mathrm{Ab}$ & $161.33 \pm 16.8 \mathrm{Ab}$ & $154.33 \pm 21.1 \mathrm{Ab}$ \\
\hline
\end{tabular}

Surface profilometry, p-values: treatment, $<0.0001 ;$ smoke,$=0.0083$; treatment and smoke, $=0.1035$. Surface Roughness, $\mathrm{p}$-values: treatment, $<0.0001 ;$ smoke,$=0.2319$; treatment and smoke, $=0.3244$. Different letters (upper case for exposure to cigarette smoke and lower case for treatment) indicate statistically significant differences $(p \leq 0.05)$.

The 3D images of the enamel surface topography (Figure 2) showed no differences between the presence and absence of cigarette smoke exposure for the same treatment. The distilled water group had greater demineralization, showing a rough, irregular, and peaked surface with small, shallow depressions and irregular margins. The depths of tissue loss were 3.5 and 3.7 with distilled water, 2.5 and 2.7 with NaF, 2.1 and 2.1 with F/bioactive glass, 1.2 and 1.6 with $\mathrm{SnF}_{2}, 0.56$ and 0.59 with $\mathrm{F} / \mathrm{Sn} /$ chitosan, and 1.20 and 1.40 with $\mathrm{F} / \mathrm{CaSiO}{ }_{3} / \mathrm{Na}_{3} \mathrm{PO}_{4}$, with and without cigarette smoke exposure, respectively. $\mathrm{NaF}$ and $\mathrm{F} /$ bioactive glass showed a characteristic honeycomb appearance resulting from the dissolution of nuclei and sheath areas of the prism, but with relatively sound interprismatic areas. $\mathrm{SnF}_{2}$ showed a fairly defined demineralization pattern, but with a low difference between the heights of the surface peaks and valleys, which may have resulted in the low Ra values. The presence of surface precipitates was verified. $\mathrm{F} / \mathrm{Sn} /$ chitosan and $\mathrm{F} / \mathrm{CaSiO}{ }_{3} / \mathrm{Na}_{3} \mathrm{PO}_{4}$ had the same performance. They promoted more regular surface demineralization and showed no honeycomb pattern and a thicker layer of surface precipitates.

\section{Discussion}

Cigarette smoking promoted changes in dental enamel (Table 2) after exposure to 20 cigarettes per day for 5 days increased SMH, as previous reported, ${ }^{15}$ probably because of the incorporation of heavy metals, such as lead, cadmium and arsenic. ${ }^{6}$ Indeed, heat can alter the hydroxyapatite crystal morphology. ${ }^{5}$

Despite increased SMH, smoking did not improve enamel resistance to erosive challenges, as measured by SMH and profilometry. Dental enamel is highly mineralized. ${ }^{7}$ The crystals consist of a Ca-deficient $\mathrm{CO}^{2-}$-rich hydroxyapatite with a $\mathrm{Ca} / \mathrm{P}$ ratio of 1.61 instead of 1.66, as in hydroxyapatite. ${ }^{19}$ The simplified formula for tooth mineral is $\mathrm{Ca}_{10 \mathrm{x}} \mathrm{Na}_{\mathrm{n}}\left(\mathrm{PO}_{4}\right)_{6-\mathrm{y}}\left(\mathrm{CO}_{3}\right)$ ${ }_{z}(\mathrm{OH})_{2-\mathrm{u}} \mathrm{F}_{\mathrm{u}}$, which is different from the $\mathrm{Ca}_{10}\left(\mathrm{PO}_{4}\right)_{6}(\mathrm{OH})_{2}$ of hydroxyapatite..$^{19}$ During an acid attack, $\mathrm{H}^{+}$ions are released from the acid and adhere to different sites on hard dental-tissue surfaces. ${ }^{7}$ Additionally, $\mathrm{PO}_{4}{ }^{3-}$ and $\mathrm{OH}^{-}$concentrations decrease at lower $\mathrm{pH}^{7}$. These ions dissolve from teeth to maintain the equilibrium of the solution around the surface ${ }^{7}$. In this study, changes in SMH after exposure to cigarette smoke might not have interfered with the amount of $\mathrm{Ca}^{2+}, \mathrm{PO}_{4}{ }^{3-}, \mathrm{OH}^{-}$, or $\mathrm{F}^{-}$. Moreover, the erosive process depends not only on crystal solubility at the tooth surface but also on the liquid surrounding the tooth..$^{20}$ In this study, all groups were eroded with the same solution.

Exposure to cigarette smoke resulted in greater enamel loss, as shown by surface profilometry (Table 3 ). This may have occurred because of the enamel heating caused by the smoke. ${ }^{5}$ The change in hydroxyapatite crystal morphology may have decreased its resistance to low $\mathrm{pH}$. The greatest loss of dental tissue may also be associated with the incorporation of heavy metals ${ }^{6}$. Until recently, studies did not investigate which enamel region the metals were adsorbed in or how they bond with hydroxyapatite crystals. The metals 

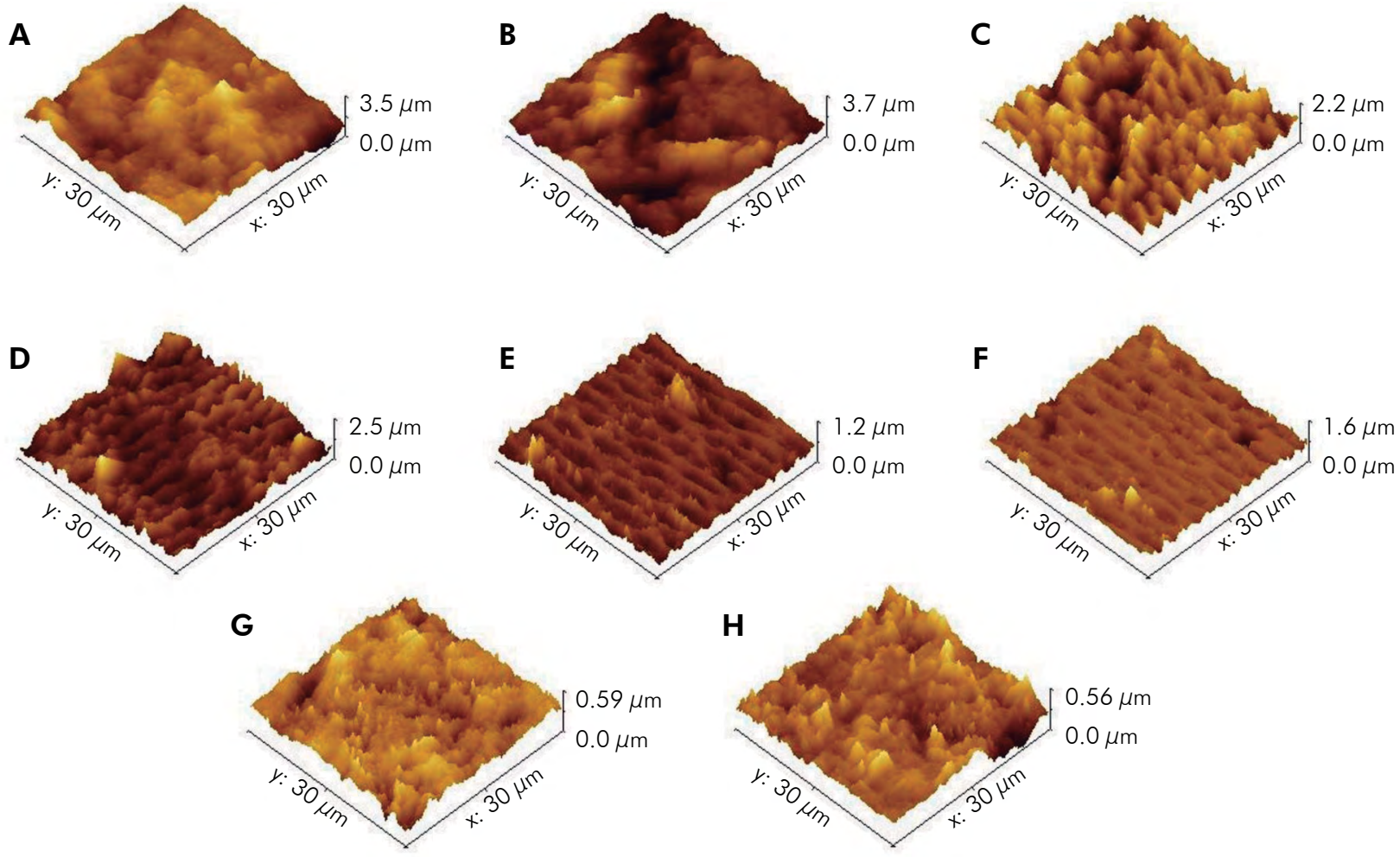

Figure 2. 3D images of enamel surface topography $(30 \times 30 \mu \mathrm{m})$ under the atomic force microscope. (A) enamel eroded and treated with distilled water, $(B)$ enamel exposed to cigarette smoke and eroded and treated with distilled water, (C) enamel eroded and treated with $\mathrm{NaF}$, (D) enamel exposed to cigarette smoke and eroded and treated with $\mathrm{NaF}$, (E) enamel eroded and treated with $\mathrm{SnF}_{2},(\mathrm{~F})$ enamel exposed to cigarette smoke and eroded and treated with $\mathrm{SnF}_{2}(\mathrm{G})$ enamel eroded and treated with $\mathrm{F} / \mathrm{Sn} /$ chitosan, $(H)$ enamel exposed to cigarette smoke and eroded and treated with $\mathrm{F} / \mathrm{Sn} / \mathrm{chitosan}$.

may be occupying a susceptible area in the enamel prism, making it more soluble. Further studies are needed to better elucidate the interactions between cigarette smoke and dental enamel.

In this study, the acquired pellicle was produced using human saliva, with and without exposure to cigarette smoke, even in the presence of remineralizing agents. The pellicle can interact with some of the anti-erosive agents used, such as $\mathrm{F}, \mathrm{Sn}$, and Chitosan, modifying their protective effects. ${ }^{11}$ The acquired film proteins can influence the formation and stabilization of $\mathrm{CaF}_{2}$ precipitates on the enamel surface after exposure to fluoride because of the adsorption of $\mathrm{PO}_{4}{ }^{3-}$ and proteins, increasing the efficacy of fluoride treatment. ${ }^{21}$ The presence of $\mathrm{Sn}$ ions is associated with the retention of abundant protein from the acquired pellicle, ${ }_{1}^{11}$ which may explain the efficacy of Sn-based compounds in this study. Additionally, the pellicle acts as a barrier with selective permeability that prevents direct contact between erosive acids and the tooth surface, thereby reducing demineralization..$^{22}$ Most laboratory studies used artificial saliva, thereby preventing adequate formation of the acquired film, which might impact the erosion. ${ }^{23}$ Ideally, in vitro erosion models should incorporate exposure to natural human saliva ${ }^{23}$ because all of these factors and modulators of dental erosion.

Natural saliva has some limitations with in vitro models, such as rapid decomposition and possibility of contamination. ${ }^{24}$ Therefore, several studies used artificial saliva. ${ }^{24}$ An in vitro study compared the remineralizing capacities of human saliva, artificial saliva, and remineralizing solution, and microradiography showed no significant differences in mineral loss among them. ${ }^{25}$ The use of natural saliva for storage in this study would require the collection of abundant saliva for the many days of erosive cycle 
and number of study groups, which was not feasible, and artificial saliva was chosen for storage.

Enamel repair and protection may be enhanced by the use of fluoride-containing products. ${ }^{7}$ Toothpaste is a vehicle for supplying fluoride in the oral cavity, with good availability. However, brushing promotes dental wear by removing the soft enamel layer, especially after an erosive challenge. ${ }^{26}$ Enamel abrasion by brushing is influenced mainly by toothpaste abrasiveness, ${ }^{27}$ which varies between the marketed toothpastes in relation to enamel and dentin. ${ }^{27}$ In this study, toothbrushing was not performed, which may be a limitation. However, as several toothpastes were used, brushing was not designed because the abrasiveness could not be standardized. Therefore, the effects of active agents from toothpastes were assessed, excluding their potential of abrasiveness. In clinical situations, these results may be different because depending on the toothpaste type, erosion can be greater than the protective effect of the active ingredients.

The action of fluoride seems to be limited in erosion and does not provide total protection. ${ }^{9}$ Therefore, it is necessary to combine fluoride with other agents. ${ }^{7}$ In this study, $\mathrm{NaF}$ had more anti-erosive effects only in relation to the negative control treated to distilled water, as previously reported ${ }^{28}$. Under acidic conditions, the $\mathrm{NaF}$ action of forming a $\mathrm{CaF}_{2}$ layer on demineralized surfaces is reduced at low $\mathrm{pH}^{9}$. This impairs the effect of NaF-based toothpastes on the prevention of erosion. ${ }^{9} \mathrm{NaF}$ is a saliva-dependent compound, as it demonstrates similar efficacy to fluoride-free toothpastes in low salivary flow conditions. ${ }^{29}$

In general, Sn-based toothpastes showed the best results. The combination of fluoride with $\mathrm{Sn}$ and Chitosan is more efficient than NaF.1216,29 Their mode of action is mostly based on the reaction between $S n$ ions and hard dental tissues to form $\mathrm{Sn}_{2} \mathrm{OHPO}_{4}, \mathrm{Sn}_{3} \mathrm{~F}_{3} \mathrm{PO}_{4}$, and $\mathrm{Ca}\left(\mathrm{SnF}_{3}\right)_{2}$ salts. ${ }^{30} \mathrm{SnF}_{2}$ can interact with and be incorporated in the eroded enamel ${ }^{21}$, forming salts with $\mathrm{Ca}$ and $\mathrm{PO}_{4}{ }^{3-},{ }^{30}$ which are more acid-resistant ${ }^{31}$. Additionally, several studies have confirmed the effectiveness of $\mathrm{SnF}_{2}$ in the presence of an acquired pellicle ${ }^{11,29}$. Sn ions were suggested to have a crosslinking action with proteins of a previously formed acquired pellicle, ${ }^{32}$ including mucins and albumins. ${ }^{11}$ In the 3D images (Figure 2), demineralization had a similar honeycomb appearance with the use of distilled water and $\mathrm{SnF}_{2}$, but with less depth, which was probably a reason for the low Ra values.

The combination of chitosan with Sn and fluoride compounds showed the same effect as $\mathrm{SnF}$ on tissue loss and Ra $(p<0.05)$ (Table 3). They had the best effect against erosion. Furthermore, chitosan showed lower \%SMH2 and higher SMH3 than Sn ( $p>0.05)$ (Table 2). This result shows that after erosive challenge, $\mathrm{F} / \mathrm{Sn} / \mathrm{Chitosan}$ hardens the enamel more than SnF does, which may benefit in facing subsequent erosive challenges. Chitosan is a natural polymer derived from chitin de-acetylation. This polymer binds to salivary proteins, ${ }^{33}$ fluoride, ${ }^{7}$ and other ions on the enamel surface, ${ }^{34}$ forming layers that are acidresistant and providing better protection against demineralization. ${ }^{34}$ Moreover, this layer can increase Sn retention, ${ }^{16}$ thereby increasing its protective effect. In this toothpaste, $\mathrm{Sn}$ is combined with AmF. The Sn ion needs to be stabilized in an aqueous solution, particularly in neutral formulations. ${ }^{12} \mathrm{Sn}$ is better stabilized when combined with $\mathrm{AmF}^{30}$ In addition, this toothpaste has $\mathrm{SnCl}_{2}$, thus increasing the $\mathrm{Sn}$ amount in the toothpaste. The effects of chitosan and Sn were evident in the 3D images of the enamel surface (Figure 2), as a reduced pattern of demineralization and an aprismatic layer, allowing the identification of crystals precipitated from the remineralizing agents. However, \%SMH2 showed that the effect of chitosan-based toothpastes is limited after enamel is exposed to smoke. Probably, contaminants prevent the formation of chitosan layers under the eroded enamel. In contrast, the protection of $\mathrm{SnF}_{2}$ was higher in the enamel exposed to cigarettes. Being a metal, Sn can depose itself and form stable salts with hydroxyapatite crystals, as shown above. ${ }^{30}$

Another toothpaste evaluated in this study had $\mathrm{F} / \mathrm{CaSiO}{ }_{3} / \mathrm{Na}_{3} \mathrm{PO}_{4}$. Studies show that $\mathrm{CaSiO}_{3}$ can deposit on the enamel surface and release $\mathrm{Ca}$ ions into oral fluids under acidic conditions, increasing the degree of hydroxyapatite saturation, and inhibit the dissolution of tooth enamel, ${ }^{35}$ however, in this study, this deposit did not resist the acidic effect. $\mathrm{F} / \mathrm{CaSiO}{ }_{3} / \mathrm{Na}_{3} \mathrm{PO}_{4}$ showed a great loss of tissue, better 
only than distilled water (Table 3). Furthermore, $\mathrm{CaSiO}_{3}$ can nucleate hydroxyapatite crystals, ${ }^{36}$ as seen in the topographic 3D images (Figure 2). This may have favored the results of SMH and \%SMH because this toothpaste presented results similar to $\mathrm{F} / \mathrm{Sn} /$ chitosan $(p<0.05)$. Similarly, $\mathrm{F} /$ bioactive glass promoted the precipitation of $\mathrm{Na}, \mathrm{Ca}$ and $\mathrm{PO}_{4}{ }^{3-}$ ions, which also interact with oral fluids to form a layer of crystallized hydroxy-carbonate apatites, similar to the enamel ${ }^{37}$, and minimize any changes in $\mathrm{SMH}$. However, these beneficial effects may be verified in the remaining enamel that is underneath the lost enamel after the erosive challenge. The surface profilometry results (Table 3 ) showed that $\mathrm{F} / \mathrm{CaSiO} \mathrm{N}_{3} / \mathrm{Na}_{3} \mathrm{PO}_{4}$ and $\mathrm{F} /$ bioactive glass were not enough to prevent mineral loss, as they did not differ statistically from $\mathrm{NaF}$.

$\mathrm{F} / \mathrm{CaSiO}{ }_{3} / \mathrm{Na}_{3} \mathrm{PO}_{4}$ and $\mathrm{F} /$ bioactive glass have MFP as a fluoride agent. In cases of in vitro studies on MFPbased toothpastes, the type of diluent used in the slurry should be considered. The bioavailability of fluoride can be affected not only by the composition ${ }^{38}$ but also by interactions with human saliva. MFP hydrolysis is catalyzed by salivary enzymes that decrease the efficacy of MFP-containing toothpastes in in vitro studies. ${ }^{39}$ Therefore, there are few published studies testing the effectiveness of MFP against erosive challenges. These factors may have contributed to the low efficacy of these toothpastes.

\section{Conclusion}

Cigarette smoking may be considered a modulator of dental erosion by causing superficial changes in the enamel. The increase in SMH exposed to cigarette smoke was not enough to inhibit demineralization of the tooth enamel in the erosion cycle. However, the exposure to cigarette smoke resulted in a greater loss of tissue for all groups, except $\mathrm{F} / \mathrm{CaCO} \mathrm{CO}_{3} / \mathrm{Na}_{3} \mathrm{PO}_{4}$, as seen in surface profilometry analysis. The $\mathrm{NaF}$-containing toothpaste showed a limited efficacy against dental erosion. Sn and its combinations with chitosan and fluoride would yield promising compounds, as it had the best performance and anti-erosive action among all evaluated toothpastes.

\section{Acknowledgements}

We thank the volunteers who donated their saliva. Our gratitude to Dr Lívia Maria Andaló Tenuta, Professor at University of Michigan, School of Dentistry, Ann Arbor, MI, USA for help during the elaboration of the research Project and methodology. Gratitude also to the support offered by Department of Oral and Biochemistry, Piracicaba Dental School, University of Campinas - FOP/UNICAMP. We also thank LAMULT (Laboratory of Multiusers of the Institute of Physics “Gleb Wataghin"), University of Campinas - UNICAMP, for offering us support and assistance in the analysis of surface profilometry and AFM.

\section{References}

1. Magalhães AC, Wiegand A, Young A, Schlueter N. Dental erosion. Int J Dent. 2012;2012:356021. https://doi.org/10.1155/2012/356021

2. Bobo JK, Husten C. Sociocultural influences on smoking and drinking. Alcohol Res Health. 2000;24(4):225-32.

3. Mann AP, Accurso EC, Stiles-Shields C, Capra L, Labuschagne Z, Karnik NS, et al. Factors associated with substance use in adolescents with eating disorders. J Adolesc Health. 2014 Aug;55(2):182-7. https://doi.org/10.1016/i.jadohealth.2014.01.015

4. Torikai K, Yoshida S, Takahashi $\mathrm{H}$. Effects of temperature, atmosphere and $\mathrm{pH}$ on the generation of smoke compounds during tobacco pyrolysis. Food Chem Toxicol. 2004 Sep;42(9):1409-17. https://doi.org/10.1016/i.fct.2004.04.002

5. Palamara J, Phakey PP, Rachinger WA, Orams HJ. The ultrastructure of human dental enamel heat-treated in the temperature range 200 degrees C to 600 degrees C. J Dent Res. 1987 Dec;66(12):1742-7. https://doi.org/10.1177/00220345870660120901

6. Takeuchi CY, Corrêa-Afonso AM, Pedrazzi H, Dinelli W, Palma-Dibb RG. Deposition of lead and cadmium released by cigarette smoke in dental structures and resin composite. Microsc Res Tech. 2011 Mar;74(3):287-91. https://doi.org/10.1002/jemt.20903

7. Lussi A, Carvalho TS. The future of fluorides and other protective agents in erosion prevention. Caries Res. 2015;49 Suppl 1:18-29. https://doi.org/10.1159/000380886

8. Hooper SM, Newcombe RG, Faller R, Eversole S, Addy M, West NX. The protective effects of toothpaste against erosion by orange juice: studies in situ and in vitro. J Dent. 2007 Jun;35(6):476-81. https://doi.org/10.1016/i.jdent.2007.01.003 
9. Moretto MJ, Magalhães AC, Sassaki KT, Delbem AC, Martinhon CC. Effect of different fluoride concentrations of experimental dentifrices on enamel erosion and abrasion. Caries Res. 2010;44(2):135-40. https://doi.org/10.1159/000302902

10. Magalhães AC, Wiegand A, Rios D, Buzalaf MA, Lussi A. Fluoride in dental erosion. Monogr Oral Sci. 2011;22:158-70. https://doi.org/10.1159/000325167

11. Algarni AA, Mussi MC, Moffa EB, Lippert F, Zero DT, Siqueira WL, et al. The impact of stannous, fluoride ions and its combination on enamel pellicle proteome and dental erosion prevention. PLoS One. 2015 Jun;10(6):e0128196. https://doi.org/10.1371/journal.pone.0128196

12. Ganss C, von Hinckeldey J, Tolle A, Schulze K, Klimek J, Schlueter N. Efficacy of the stannous ion and a biopolymer in toothpastes on enamel erosion/abrasion. J Dent. 2012 Dec;40(12):1036-43. https://doi.org/10.1016/i.jdent.2012.08.005

13. Mosquim V, Martines Souza B, Foratori Junior GA, Wang L, Magalhães AC. The abrasive effect of commercial whitening toothpastes on eroded enamel. Am J Dent. 2017 Jun;30(3):142-6.

14. Serra MC, Cury JA. The in vitro effect of glass-ionomer cement restoration on enamel subjected to a demineralization and remineralization model. Quintessence Int. 1992 Feb;23(2):143-7.

15. Bertoldo CE, Miranda DA, Souza Junior EJ, Aguiar FH, Lima DA, Ferreira RL, et al. Surface hardness and color change of dental enamel exposed to cigarette smoke. Int J Dent Clin. 2011;3:1-4.

16. Carvalho TS, Lussi A. Combined effect of a fluoride-, stannous- and chitosan-containing toothpaste and stannous-containing rinse on the prevention of initial enamel erosion-abrasion. J Dent. 2014 Apr;42(4):450-9. https://doi.org/10.1016/i.jdent.2014.01.004

17. Danelon M, Pessan JP, Santos VR, Chiba EK, Garcia LS, Camargo ER, et al. Fluoride toothpastes containing micrometric or nano-sized sodium trimetaphosphate reduce enamel erosion in vitro. Acta Odontol Scand. 2018 Mar;76(2):119-24. https://doi.org/10.1080/00016357.2017.1388442

18. Carvalho TS, Baumann T, Lussi A. In vitro salivary pellicles from adults and children have different protective effects against erosion. Clin Oral Investig. 2016 Nov;20(8):1973-9. https://doi.org/10.1007/s00784-015-1703-1

19. Featherstone JD, Mayer I, Driessens FC, Verbeeck RM, Heijligers HJ. Synthetic apatites containing Na, Mg, and CO3 and their comparison with tooth enamel mineral. Calcif Tissue Int. 1983;35(2):169-71. https://doi.org/10.1007/BF02405026

20. Lussi A, Hellwig E, Klimek J. Fluorides: mode of action and recommendations for use. Schweiz Monatsschr Zahnmed. 2012;122(11):1030-42.

21. Schlveter N, Hardt M, Lussi A, Engelmann F, Klimek J, Ganss C. Tin-containing fluoride solutions as anti-erosive agents in enamel: an in vitro tin-uptake, tissue-loss, and scanning electron micrograph study. Eur J Oral Sci. 2009 Aug;117(4):427-34. https://doi.org/10.1111/j.1600-0722.2009.00647.x

22. Wiegand A, Bliggenstorfer S, Magalhaes AC, Sener B, Attin T. Impact of the in situ formed salivary pellicle on enamel and dentine erosion induced by different acids. Acta Odontol Scand. 2008 Aug;66(4):225-30. https://doi.org/10.1080/00016350802183401

23. Buzalaf MA, Hannas AR, Kato MT. Saliva and dental erosion. J Appl Oral Sci. 2012 Sep-Oct;20(5):493-502. https://doi.org/10.1590/S1678-77572012000500001

24. Hara AT, González-Cabezas C, Creeth J, Zero DT. The effect of human saliva substitutes in an erosion-abrasion cycling model. Eur J Oral Sci. 2008 Dec;116(6):552-6. https://doi.org/10.1111/j.1600-0722.2008.00575.x

25. Amaechi BT, Higham SM. In vitro remineralisation of eroded enamel lesions by saliva. J Dent. 2001 Jul;29(5):371-6. https://doi.org/10.1016/S0300-5712(01)00026-4

26. Rios D, Honório HM, Magalhães AC, Delbem AC, Machado MA, Silva SM, et al. Effect of salivary stimulation on erosion of human and bovine enamel subjected or not to subsequent abrasion: an in situ/ex vivo study. Caries Res. 2006 MayJun;40(3):218-23.

27. Wiegand A, Kuhn M, Sener B, Roos M, Attin T. Abrasion of eroded dentin caused by toothpaste slurries of different abrasivity and toothbrushes of different filament diameter. J Dent. 2009 Jun;37(6):480-4. https://doi.org/10.1016/i.jdent.2009.03.005

28. West NX, Seong J, Hellin N, Eynon H, Barker ML, He T. A clinical study to measure anti-erosion properties of a stabilized stannous fluoride dentifrice relative to a sodium fluoride/triclosan dentifrice. Int J Dent Hyg. 2017 May;15(2):113-9. https://doi.org/10.1111/idh.12159

29. Pini NI, Schlueter N, Sundfeld D, Semper Hogg W, Santos-Silva AR, Lopes MA, et al. Efficacy of Stannous lons on Enamel Demineralization under Normal and Hyposalivatory Conditions: A Controlled Randomized in situ Pilot Trial. Caries Res. 2018 Jan;51(6):543-53. https://doi.org/10.1159/000479041

30. Schlveter N, Klimek J, Ganss C. Randomised in situ study on the efficacy of a tin/chitosan toothpaste on erosive-abrasive enamel loss. Caries Res. 2013;47(6):574-81. https://doi.org/10.1159/000351654

31. Hove L, Holme B, Øgaard B, Willumsen T, Tveit AB. The protective effect of TiF4, SnF2 and NaF on erosion of enamel by hydrochloric acid in vitro measured by white light interferometry. Caries Res. 2006;40(5):440-3. https://doi.org/10.1159/000094291

32. Veeregowda DH, Mei HC, Busscher HJ, Sharma PK. Influence of fluoride-detergent combinations on the visco-elasticity of adsorbed salivary protein films. Eur J Oral Sci. 2011 Feb;119(1):21-6. https://doi.org/10.1111/i.1600-0722.2010.00798.x

33. Keegan GM, Smart JD, Ingram MJ, Barnes LM, Burnett GR, Rees GD. Chitosan microparticles for the controlled delivery of fluoride. J Dent. 2012 Mar;40(3):229-40. https://doi.org/10.1016/i.jdent.2011.12.012

34. Ganss C, Lussi A, Grunau O, Klimek J, Schlueter N. Conventional and anti-erosion fluoride toothpastes: effect on enamel erosion and erosion-abrasion. Caries Res. 2011;45(6):581-9. https://doi.org/10.1159/000334318 
35. Sun Y, Li X, Deng Y, Sun JN, Tao D, Chen H, et al. Mode of action studies on the formation of enamel minerals from a novel toothpaste containing calcium silicate and sodium phosphate salts. J Dent. 2014 Jun;42 Suppl 1:S30-8. https://doi.org/10.1016/S0300-5712(14)50005-X

36. Parker AS, Patel AN, Al Botros R, Snowden ME, McKelvey K, Unwin PR, et al. Measurement of the efficacy of calcium silicate for the protection and repair of dental enamel. J Dent. 2014 Jun;42 Suppl 1:S21-9. https://doi.org/10.1016/S0300-5712(14)50004-8

37. Wefel JS. NovaMin: likely clinical success. Adv Dent Res. 2009;21(1):40-3. https://doi.org/10.1177/0895937409335622

38. Faller RV, Pfarrer AM, Eversole SL, Cox ER, Landrigan WF, Wang Q. The comparative anticaries efficacy of Crest toothpaste relative to some marketed Chinese toothpastes - results of in vitro pH cycling testing. Int Dent J. 1997;47(6):313-20. https://doi.org/10.1111/j.1875-595X.1997.tb00455.x

39. Ekambaram M, Itthagarun A, King NM. Comparison of the remineralizing potential of child formula dentifrices. Int J Paediatr Dent. 2011 Mar;21(2):132-40. https://doi.org/10.1111/j.1365-263X.2010.01101.x 